\title{
Panel calls for technology company
}

\section{Washington}

CALLING for a $\$ 5,000$ million "civilian technology corporation", the National Academy of Sciences last week recommended that the US government match technical and manufacturing advances in other countries by funding 'pre-commercial' research and development (R\&D).

Although the Academy report* acknowledges that the US high-technology industry remains relatively healthy on such measures as productivity per capita and trade balance, it points out such warning signs as a decline in R\&D spending and the sluggish transfer of technology from government research laboratories to industry.

Market forces and existing ways to transfer technology are not enough to keep the United States competitive, the report concludes; the government must intervene. However, the right sort of interven- tion remains controversial. After raising and dismissing such solutions as having existing agencies spend more on pre-commercial R\&D (the disadvantage: no real mandate for change) and creating a new agency modelled after a civilian Defense Advanced Research Projects Agency (too vulnerable to politics), the NAS panel reluctantly settled on an independent technology corporation. Although it, too, could be influenced by politics and hindered by the absence of clear market signals, "it was the least bad solution," said Harold Brown, the chairman of the panel and a former Secretary of Defense.

The report also calls for an 'Industrial Extension Service' at the US Department of Commerce, modelled after the venerable extension programmes of the US Department of Agriculture. The panel recommended that a few of the 700 federal

\section{Economic crisis squeezes data}

\section{London}

A LACK of money to operate a fleet of Russian research vessels is undermining an international system that monitors the salinity and temperature of the upper layer of the world's oceans. In addition, the rise of capitalism in the former Soviet Union is expected to drive up the future cost of operating such a system.

A quarter of the 155 ships that contribute data to the Integrated Global Ocean Services System (IGOSS) are maintained by the states of the former Soviet Union. But only four of the 38 research and commercial vessels that participated in IGOSS have been active since the coup last $\mathrm{Au}$ gust that led to the final dissolution of the Soviet system. The rest of Russia's 120ship research fleet is similarly grounded.

Run jointly by the World Meteorological Organisation (WMO) and the Intergovernmental Oceanographic Commission (IOC), IGOSS relies on data collected voluntarily by the crews of research and commercial vessels all over the world. The information is fed into the WMO Global Telecommunications System, where it is picked up by meteorologists and the few oceanographers doing 'realtime' research. After a month the data are archived for longer-term studies.

"The Soviets were a major contributor of this type of data, and we saw a drastic drop in the data flow around the time of the coup," said Tim Wright, coordinator of IGOSS operations. "They have an excellent oceanographic fleet, which is now just sitting at pier. If not used, the ships tend to go downhill fast. It's a pretty grim situation."

The ships are operated by a number of agencies, including the Russian Academy of Sciences, the Committee for Geology Research and the Russian Hydrometeorology Committee. In some cases ownership is unclear, as with a dispute between Russia and Ukraine involving jurisdiction over the Black Sea fleet.

Alexander Metalnikov of the hydrometeorology committee says that he hopes the financial difficulties can be resolved and that money can be found soon to operate the vessels. But he acknowledges that efforts to find sponsors for the committee's 24 research ships have so far been unsuccessful. Rehabilitating as few as five would be useful, he says. A typical 1,500 -ton research vessel costs about $\$ 10,000$ to $\$ 20,000$ a year to operate.

Compounding the problem is the fact that the owners of Russian commercial ships that participated in IGOSS now want to be paid for their work. Under the old, state-run system, their contributions were provided at no cost to the scientific community.

The old order of the Soviet Union was singularly good at organizing the sort of large-scale operation that supported IGOSS, and its ships contributed a large number of datasets from all over the world. In particular, they covered areas in the northern seas and in the Pacific that were seldom visited by other nations, and their crews were particularly diligent in taking salinity measurements.

Salinity data are important in predicting the way masses of water behave when they meet. They are also important in understanding how fresh water flows into the sea and the evaporation cycle.

lan Mundell laboratories be converted into facilities that would demonstrate federal technology to industry.

At the heart of the report is its call for a civilian technology corporation. Funded by a one-time, $\$ 5,000$ million appropriation and managed by a politically appointed board, the company would support R\&D by funding industrial research. Proposals would come from industry itself, the panel was careful to note; eager to avoid the stigma of 'industrial policy', the report argues that such 'bottom-up' economic support would not interfere with market forces.

Real-world examples of such a corporation are scarce. At a press conference last week, Brown cited the Communications Satellite Company (Comsat) and the ill-fated Synthetic Fuels Corporation. But Comsat concentrates on telecommunications, and the synfuels company went under in 1986 after oil prices dropped.

How the corporation would work is still an open question. Start-up funding, loans and joint ventures with industry are all possibilities, said Brown, adding that "we'll leave it to its directors".

The idea itself was enough for US Sen. Ernest Hollings (Democrat, South Carolina), who had asked for the report. At a hearing last week, Hollings announced that he would introduce legislation to create such a civilian technology corporation. But its chance of passage, concedes one staff member, are "bleak".

Christopher Anderson

*The Government Role in Civilian Technology: Building a New Alliance, National Academy of Sciences, 1992.

\section{BIOTECH PATENTS}

\section{Australia says yes}

\section{Sydney}

AN Australian parliamentary committee says that the government should permit the patenting of live organisms and that any objections to genetically modified organisms should be dealt with by other means. The report, by the Standing Committee on Industry, Science and Technology, is not expected to be challenged by the rest of Parliament. Its significance is heightened by the fact that Australia is the only country so far to approve such a live organism for general release.

The committee's report concentrates on setting guidelines for the conditions under which such organisms should be used. It recommends that existing, semivoluntary approved processes be strengthened and given the force of law. It also calls for a formal mechanism to obtain approval for the release of both live organisms and those that are by-products of such genetic engineering.

Mark Lawson 